УДК 821.134.41'36:811.112.2 Караџић, Вук Стефановић https://doi.org/10.18485/msc50_vuk_trsic.2021.ch8

\author{
Петер Редер
}

\title{
ГРИМОВ ЛИЧНИ ПРИМЕРАК ПРЕВОДА ВУКОВЕ СРПСКЕ ГРАМАТИКЕ
}

Као што је већ опште познато, Српска граматика Вука Стефановића Караџића, која је претходила његовом Српском рјечнику из 1818, појавила се већ 1824. у немачком преводу Јакоба Грима. Још и данас је то врло зачуђујућа чињеница, јер не само да је временска разлика између оригинала и превода незнатна, већ и изненађује за то време необично интересовање за превођење и издавање једне српске граматике. И данас је још изузетак да се једна словенска граматика тако брзо и одушевљено преведе на немачки. Кључ за разумевање читаве ове сјајне акције налази се у великом одушевљењу Јакоба Грима за српскохрватске народне песме и њихов језик. Ово одушевљење превазилази чисто научно интересовање. Али се исто тако не сме предвидети Вукова загрејаност да се његова граматика преведе на немачки као и Копитарево свесрдно и живо интересовање за то.

Пошто из Вукове преписке знамо да је Грим мењао текст, дакле допуњавао и кориговао понешто у преводу Димитрија Тирола као и да је користио нов, Караџићев материјал, те стога није неинтересантно питање у чему се немачки превод разликује од српског оригинала. Гримов лични приручни примерак превода са уметнутим листовима за бе-

1 Знатно проширен члан о Гримовом преводу и примерку Караџићеве Српске граматике штампа се у часопису „Südostforschungen” на немачком језику. Овде само најважнија литература: Караџић В. Ст.: Српски ријечник, истолкован ғемачким и татинским ријечима, у Бечу 1818. (Фототипско издање, Београд 1966) - Караџић, В. Ст.; Kleine serbische Grammatik, übersetzt und mit einer Vorrede von Jacob Grimm (1824). Neu herausgegeben und eingeleitet von Miljan Mojašević und Petar Rehder, München 1974. - Вукова преписка, Књига друга, београд 1908, 1-67, - Стојановић Љуб. Живот и рад Вука Стеб. Караџића; Београд 1924. - Мојашевић Миљан, Гримов превод и примерак Карацићеве граматике, Анали Филолошког факултета 5, 1966, 159-171. 
лешке, који професор Мојашевић прилаже овом састанку као репринт, омогућује бољи увид у активност немачког слависте Јакоба Грима, која показује како је Грим деценијама радио и сабирао грађу за српску граматику. Овај Гримов лични примерак са уметнутим листовима је извор наших сазнања и сведочанство његових погледа, споменик великих немачко-српскохрватских односа, који обавезује; а истовремено представља један рани споменик словенске филологије у Немачкој.

Које су дакле разлике између Српске граматике из 1818. и њеног немачког превода из 1824? Како Љубомир Стојановић пише у својој још данас незаменљивој биографији о Караџићу, Грим је уз материјал који је добио од Караџића „додао чланак о роду именица и израдио одељке о предлозима, прилозима, свезама и усклицима, прерадио је одељак о придевима и увод о глаголима" (стр. 242). Већ те допуне дају Гримовом преводу посебан значај; то је - може се казати без претеривања - више него прост превод. Али, погледајмо појединачно те допуне, промене редоследа, измењене и испуштене делове оригинала.

Допуне обухватају, дакле, одељак о роду именица који помиње Стојановић (немачки наслов: Von dem Geschlechte des Normens, стр. 22-25) и материјал о препозицијама, адвербима, конјукцијама и интерјекцијама додат у прилогу (немачки наслов: Von den Partikeln: I. Präpositionen, II. Adverbia, III. Conjunctionen, IV. Interjectionen, стр. 99-104). Али овим допуне нису сасвим исцрпене. Даље се могу појединачно утврдити следеће допуне.

Следећа допуна је табела српских ћирилских (или како тамо стоји: грчких) и латиничних слова са приближно одговарајућим гласовима у немачком. Истина да је и Караџић дао попис слова на крају своје Српске граматике (Alphabeti Serborum cym viciniorum popularium et aliis cultioris Europae alphabetis parallelismós, стр. LXIX), али то је само упоредни преглед слова Срба, Хрвата, Словенаца, Чеха, Пољака, Немаца, Италијана, Француза и Енглеза. Грим насупрот Вуковој табели даје свом немачком читаоцу гласовну интерпретацију српских слова. Овде је интересантно да Грим, тачно по Караџићу, даје само 28 „прости гласова”, не уносећи ф и х. Али, Вук је написао већ у фусноти уз своју табелу: „Sonos $\mathrm{f}$ i h vix invenias in vocibus genuine Serbicis; sed ultramque literam ob voces peregre adscitas ex alphabeto Cyrilliano retinuimus". И при том налазимо ф и х као гласове у поменутој граматици и њеном преводу, иако скоро само у страним речима. Ипак се ф налази као лема већ у речнику из 1818, док х налазимо тек у његовом другом издању из 1852. Грим је, дакле с једне стране, дао том табелом свом немачком читаоцу, важну допуну, а с друге стране, није допустио да на ту његову табелу утичу Вукова убедљива интерпре- 
тација страних односно периферних фонема $\mathrm{f}$ и h. Tо је по свој прилици једна мала недоследност код Грима. Стога сматрам да је у суштини та табела Гримово дело. Она је неопходна допуна за немачког читаоца.

Мање допуне се налазе на пример на странама 25. и 36/37. где Грим укратко набраја род и број у српскохрватском, или где код четврте деклинације убацује парадигму за именицу небо, и прву напомену у којој објашњава проширење основе помоћ -еm-, -ен- и -ес-. Исто важи и за напомену број 5 на 35-ој страни превода, која је вероватно такође Гримова. Објашњење личних наставака на 71. страни превода такође је допуна које нема у оригиналу.

Лако је закључити, већ из овог малог прегледа важнијих допуна, да оне испуњавају свој задатак, наиме, да дају неопходне информације читаоцу немачког говорног подручја, које читаоцу са српскохрватским, као матерњим језиком, нису преко потребне. За читаоца, са српскохрватским као матерњим језиком, централно место заузимају норме његовог језика, док су за страног читаоца и корисника граматике важна и објашњења граматичких феномена, посебно ако се принципијелно разликују од његовог језичког система. Због тога је јасно да су Гримове допуне делом изазване неопходним прилагођавањем изворог текста немачкој публици, па разлике два издања налазе у томе парцијално објашњење.

Поред допуна јављају се у преводу понеке мање измене у редоследу. Једна таква једноставна измена је на пример објашњење на пола стране о појави реченичног сантхиа, дакле појава и деловање асимилације консонанта са почетка једне речи на консонант са краја претходне речи (стр. 10-11). Ово су у ствари Караџићеви подаци, које он наводи у додатку своје граматике. Грим их је само ставио на право место. - Исто важи и за следећа три Караџићева додатка на LXXI страни његове граматике. Грим их је само навео на одговарајућим местима у свом преводу (додаци 2. и 4. на страни LXXI Српске граматике, дакле, на 71, 91, 22. страни немачког превода).

Гримове измене односе се пре свега, на увод у одељак о адјективима и на увод у одељак о глаголима. Док Вук свој одељак о адјективима почиње поделом адјектива на групе по значењу (три прва пасуса), код Грима налазимо мали увод у проблематику две флексије адјектива (типови зѐлен и зѐлени). Тај увод је сигурно неопходнији немачком читаоцу од Вукове семантичке поделе. Слично се може казати и за увод у одељак о гласовном систему; али Грим, у свом уводу у глаголски систем, сажето одбацује примену латинске и грчке класификације глагола у српскохрватском, што налазимо и код Вука. Вук је добро уочио да је подела глагола по роду (из грчке и латинске граматике), на актив, пасив 
и депонент, неприменљива на српскохрватски. Грим продужава Вукову полемику против ових неадекватних граматичких система.

У Гримовом преводу је, сем тога, понешто изостављено. Како је већ Стојановић приметио и како и сам Грим наводи у свом чувеном предговору (стр. XXI), у преводу су изостављене Вукове полемичке примедбе. Оне су могле, код читалаца на немачком говорном подручју, само да изазову пометњу, а са друге стране, Караџићу нису могле много користити у борби са противницима његове ортографске и језичке реформе. У сваком случају - то не бих желео да прећутим - још и данас се те полемичке оштрице, које су тачне и духовите истовремено, читају са великим задовољством. - Даља изостављања односе се само на мање одељке, тако на пример други одељак на стр. XLIII (Дивљи, мали... од чега се појављују делови у 2. напомени на стр. 45) и четврти одељак на стр. LV (Што је гођ...). У остала изостављена места овде се не бих упуштао.

Ако покушамо да резимирамо све те разлике између Српске граматике из 1818. и њеног превода из 1824, онда произилази да се битне разлике могу објаснити као адаптације за немачку публику. У ту сврху је у прилогу о партикулама дат важан допунски материјал. Гримов допринос који је за читаву ствар био само од користи, Вук је категорично признао пишући Гриму 6. децембра 1823.: „Mir ist leid, venn sie zu wenig ausgestrichen, verbessert, und geändert haben; denn das habe ich für unsere serbische Leser, weichen noch der wahre Begriff von Grammatik fehlt, geschrieben; aysser dem sind Sie ganz anderer Gramatiker als ich; und ich habe auch einige Fehler gemacht, welche Sie recht gut corrigiert haben..." (Вукова преписка II-18). Тако ми из ових Караџићевих речи видимо да је сарадња између њега и Грима била изванредно ефикасна и од велике користи за читав подухват.

Да Гримово интензивно бављење српском граматиком није престало објављивањем његовог превода, сведочи јединственом јасноћом његов лични примерак Српске граматике, са уметнутим листовима за белешке који садржи мноштво Гримових руком исписаних примедби. Лични примерак са уметнутим листовима налази се као позајмљени експонат Берлинске државне блиблиотеке у Музеју браће Грим у Каселу. Он садржи рукописне примедбе изван текста, на маргинама текста и на тачно 86 листова за белешке. Уз то долазе још 16, слободно уметнуих листића у егземплар; на њима су, такође, Гримове рукописне примедбе. Укупно, дакле белешке на преко стотину страна, при чему су то, у сваком случају, нотице сасвим различитог опсега. Ако међутим узмемо у обзир то да је 
Гримов предговор, Фатеров чланак о народним песмама и сама Граматика, обухватају само 176 страница, јасан је обим ових примедби.

Како се те маргиналије и опаске могу класификовати и какав је њихов значај?

На ова два питања ја овде не могу дати исцрпан одговор. Морам се исто тако ограничити на примедбе уз граматику и изоставити оне које је Грим навео у свом Предговору. Пре свега треба одговорити на питање зашто је Грим уопште овакве примедбе уносио у свој примерак. Ја ни мало не сумњам у то да је пресудан мотив за овај континуирани дугогодишњи рад Гримово велико и трајно одушевљење за народне песме, а сасвим сигурно је други разлог за то његова жеља да заједно са Вуком уради друго, знатно проширено издање немачког превода. Али бацимо за тренутак поглед на ове рукописне Гримове напомене. У суштини се ради о четири подручја на које се могу поделити Гримове анотације. Прво: Грим на бројним уметнутним страницама наводи обиље српске језичке грађе. Она превасходно потиче из Вукових збирки народних песама које му је Вук редовно слао а које је Грим проучавао врло пажљиво. Уз то се налазе и изводи из Вукове „Данице”. Друго: Налазимо бројне нове исправке и допуне које је Грим унео током времена, на пример у морфонологији, где Грим настоји да алтернацију г-ж-з обухвати једним правилом. Треће: Грим даје велики број упута на стручну славистичку литературу свога времена. Најважнија имена су овде Јозеф Добровски Institutiones је Грим пажљиво проучавао, онда Копитарева словеначка граматика; уз то Боп, Брлић, Мурко, Мразовић, и наравно опет и опет радови његовог пријатеља Вука Караџића. Четврто, а то произилази из ових цитата, Грим своје преокупације проширује на словенске језике у целини при чему он узима у обзир нарочито упоредну грађу из чешког, пољског, руског и словеначког језика. Овде Грим показује велико интересовање за питање упоредне граматике словенских језика.

Да завршимо. Као што је већ рекао проф. Мојашевић у свом чланку из 1966, Грим још није критички представљен као слависта. Пошто Гримов приручни примерак сада стоји на располагању, лакше ће се дати одговор на то питање. А тај Гримов примерак заузеће посебно место у историји развоја српскохрватских граматика: као значајан споменик пријатељске сарадње два велика научника и као споменик који обавезује и дан данас.

* Рад је претходно објављен у зборнику Научни састанак слависта у Вукове дане, 4/2, 277-282. 